\title{
An Organic Nitrile Dye with Strong Donor and Acceptor Groups for Dye-Sensitized Solar Cells
}

\author{
Minshi An, Ashis Kumar Sarker, Duck-Chae Jung, and Jong-Dal Hong* \\ Department of Chemistry, University of Incheon, Incheon 406-840, Korea. *E-mail: hong5506@incheon.ac.kr \\ Received January 12, 2011, Accepted April 11, 2011
}

Key Words : Dye-to $\mathrm{TiO}_{2}$ change transfer complex, DSSC, Nitrile sensitizer, Solar cell

Due to low cost and high efficiency, dye-sensitized solar cells (DSSCs) have recently attracted extensive academic and commercial interest for the conversion of sunlight into electricity. ${ }^{1}$ Many dyes have been tested as potential sensitizers over the past two decades to improve DSSC performance. The DSSCs can be classified into two types, namely, Type I and Type II, depending on the electroninjection pathway from the dye to the conduction band (CB) of $\mathrm{TiO}_{2},{ }^{2}$ as shown in Figure 1.

First, upon light absorption, the dye molecules are excited from the highest occupied molecular orbital (HOMO) to the lowest unoccupied molecular orbital (LUMO). After excitations, the dye molecules inject electrons from the excited state into the $\mathrm{TiO}_{2}$ conduction band. This process is referred to as a "two-step" electron injection type pathway (Fig. 1, Pathway I). The Type-I dyes can be a variety of $\mathrm{Ru}(\mathrm{II})$ complexes, ${ }^{1,3}$ coumarin derivatives, ${ }^{4}$ metal-porphyrin complexes, ${ }^{5}$ and others, ${ }^{6}$ which usually possess carboxylic acid or phosphonic acid anchoring groups. Another pathway (Fig. 1, Pathway II) is the "one-step" electron injection from the HOMO of the dye to the conduction band of $\mathrm{TiO}_{2}$ by the photo-induced excitation of the dye-to- $\mathrm{TiO}_{2}$ charge-transfer (DTCT) complex. The Type-II dyes are rarely reported, compared with Type-I. As a typical example, catechol dyes having enediol units are an example of Type-II dyes that tend to strongly bind $\mathrm{TiO}_{2}$ through the chelation of surface Ti(IV) ions, giving rise to intense DTCT bands, ${ }^{2,7,8}$ which tend to appear at a wavelength longer than $320 \mathrm{~nm}$ along with local bands (arising from the dye itself). Several reports have demonstrated that the photoexcitation of DTCT bands indeed gives rise to very fast $(<100 \mathrm{fs})$ direct electron injection from the dyes to $\mathrm{TiO}_{2}{ }^{9,10}$ in compliance with the

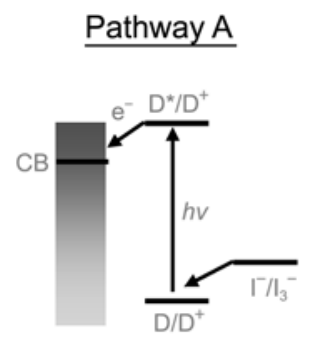

$\mathrm{TiO}_{2}$ Dye electrolyte

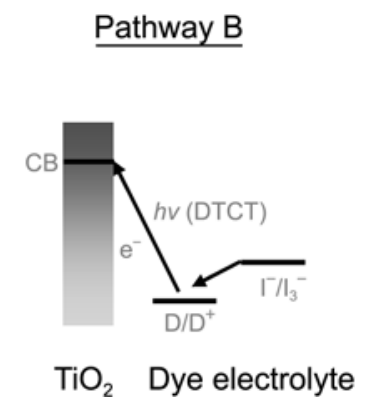

Figure 1. Two different electron injection models from adsorbed dyes into $\mathrm{TiO}_{2}$ conduction band.
Mulliken's CT theory. ${ }^{11}$

However, the efficiency of the catechol-sensitzed DSSC was generally quite low, $0.5-2.0 \% .^{6,8}$ The low efficiency arises from the fast back-electron-transfer rates from reduced $\mathrm{TiO}_{2}$ to the oxidized dye for path II in contrast to path I. In fact, large portions $(>75 \%)$ of charge recombination occur within a few picoseconds in pathway $B . .^{8 e, 10,13}$ As a result, the external quantum efficiencies arising from pathway II have never exceeded $10 \%$ in any wavelength in the absence of externally applied bias potentials.

Another compounds which have also been known to form visible CT complexes with surface Ti(IV) ions, are transitionmetal cyanides, ${ }^{14-17}$ which hence give rise to strong DTCT bands. In this respect, the nitrile dyes could be classified as Type-II dyes, which adopt the "one-step" electron injection to the $\mathrm{CB}$ of $\mathrm{TiO}_{2}$ (Pathway II) on DSSC. Thus, the development of dye systems for the electron-injection to $\mathrm{TiO}_{2}$ which occurs via both pathways I and II, ${ }^{6 \mathrm{a}, 9 \mathrm{c}, 10}$ is of great interest from academic and practical points of view. Here, we are interested in the study of the sensitizer bearing nitrile units that bind to the surface of $\mathrm{TiO}_{2}$ through the chelation of surface Ti(IV) ions. ${ }^{19}$ The best model nitrile sensitizer is 4-(dicyanomethylene)-2-methyl-6-(4-dimethylaminostyryl)$4 H$-pyran (DCM, Fig. 2), which bears both strong electronwithdrawing nitriles and an electron-donating dimethylamino group. The dipolar structure of DCM provides directionality of the electronic orbitals in the excited state. This directionality should improve the direct, "one-step" electron injection from the ground state of the dye to the $\mathrm{CB}$ of $\mathrm{TiO}_{2}$ by the photoinduced charge-transfer excitation of the dye-to$\mathrm{TiO}_{2}$ bands. ${ }^{20}$ Optimal conditions of dye adsorption onto the $\mathrm{TiO}_{2}$ were determined with respect to dye dipping solution temperature. Moreover, we fabricated solar cells with DCM,

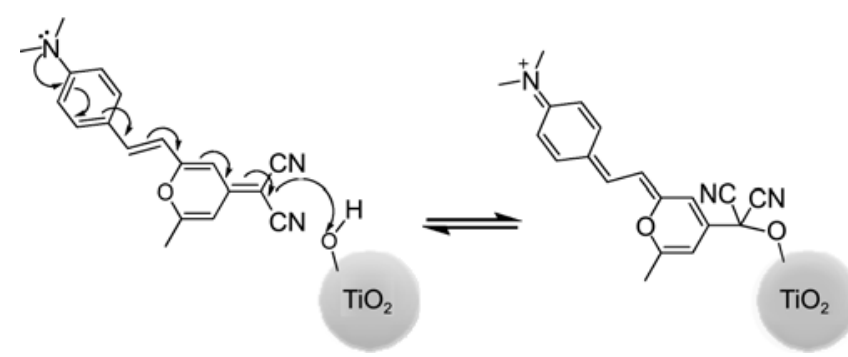

Figure 2. Molecular structure of DCM binding to the titania surface. 
and examined incident photons to the current efficiency (IPCE) and the photon conversion efficiency $(\eta)$. The best of our knowledge, this is the first report of an organic nitrile (DCM) dye applied directly to $\mathrm{TiO}_{2}$ electrode, despite the recent report about DCM that has been employed as energy relay dyes for light harvesting and photocurrent generation of DSSC via Förster resonant energy transfer. ${ }^{21-23}$

\section{Result and Discussion}

First, an FTIR-based method was employed to investigate the binding of nitrile and $\mathrm{TiO}_{2}$, as shown in Figure 3 . Therefore, the vibrational stretching band of nitrile at 2203

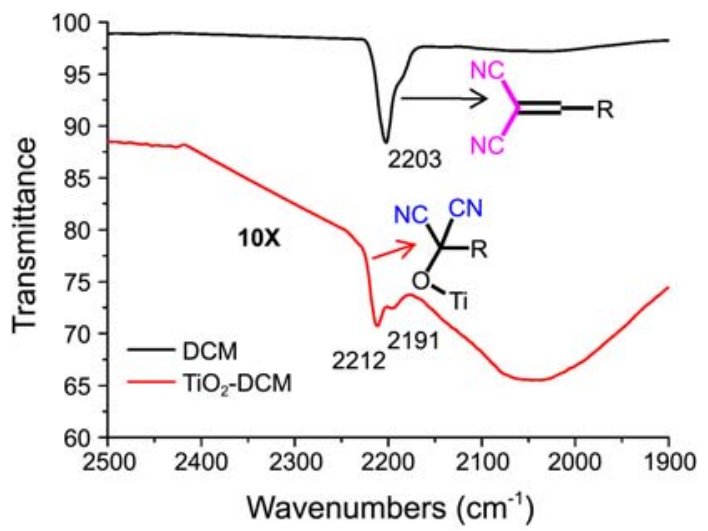

Figure 3. FTIR spectra of DCM and $\mathrm{DCM} / \mathrm{TiO}_{2}$.
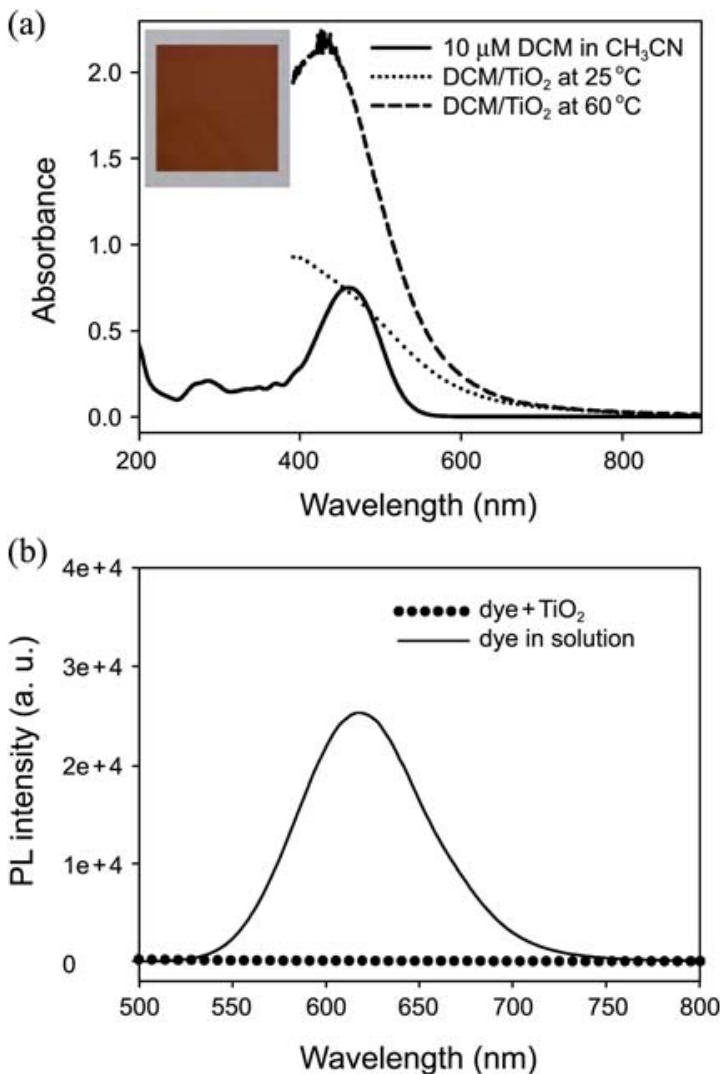

Figure 4. Absorption (a) and fluorescence (b) spectra of DCM in acetonitrile and $\mathrm{DCM} / \mathrm{TiO}_{2}$. $\mathrm{cm}^{-1}$ was split to 2212 and $2191 \mathrm{~cm}^{-1}$, which are characteristic signals for $\mathrm{N} \equiv \mathrm{C}-\mathrm{C}-\mathrm{O}-\mathrm{TiO}$ bonding formed through a nucleophilic addition reaction. ${ }^{19 b}$

DCM is relatively soluble in polar organic solvents, such as acetonitrile, acetone, and ethanol. The absorption spectrum of $\mathrm{DCM} / \mathrm{TiO}_{2}$, which is colored dark red after multiple washing steps with ethanol (insert picture), is shown in Figure 4. The adsorption of the DCM dye onto $\mathrm{TiO}_{2}$ was highly enhanced at $60^{\circ} \mathrm{C}$. The absorption spectra of DCM in acetonitrile $(10 \mu \mathrm{M})$ was shown for comparison. DCM in acetonitrile has a maximum absorption band at $470 \mathrm{~nm}$ with its onset near $550 \mathrm{~nm}$, and another band at $290 \mathrm{~nm}$ with its onset near 350. In the case of DCM, the DTCT band couldn't be clearly assigned due to strong overlap with the maximum absorption band, which considerably blue-shifted from 470 to $430 \mathrm{~nm}$. However, the broadened band width and the considerably red-shifted onsets of the local bands, compared with those of DCM in acetonitrile, indicated strong anchoring of the nitrile group on $\mathrm{TiO}_{2}$ through the chelation, giving rise to DTCT band. The interactions that most likely influence the red-shifted broad absorption structure are the molecular resonance structures of DCM. These structures have greater electron density at the cyano group, which is expected to result in stronger interactions between the cyano groups and the interior wall of the titania, anchoring DCM in the pore. Moreover, the positive charge on the dimethylamino group should result in the repulsion of neighboring DCM molecules in the cavity, favoring a twisted structural character for DCM. This structure should again facilitate the internal charge transfer processes. The titania film, which comprises 20 -nm particles, produces pore diameters between 22 and $38 \mathrm{~nm}$ and a film porosity of $68 \% .{ }^{13}$ This latter size is sufficiently large to allow DCM, of approximate dimensions $(8 \times 16) \AA^{2}$, to be incorporated into the titania film.

In addition, the fluorescence spectra of DCM $(3.5 \mu \mathrm{M})$ in acetonitrile and $\mathrm{DCM} / \mathrm{TiO}_{2}$ were collected using excitation light $\left(\lambda_{\mathrm{ex}}=461 \mathrm{~nm}\right)$, as shown in Figure 4(b). Interestingly, the fluorescence of the $\mathrm{DCM} / \mathrm{TiO}_{2}$ was found to be completely quenched due to the involvement of electron transfer reaction pathways from the $\mathrm{S} 1$ state.

The DCM-sensitized $\mathrm{TiO}_{2}$ electrode was employed as a working electrode in a sandwich-type solar cell, and the performance of the cell was characterized by spectral photocurrent responses and photocurrent-photovoltage characteristics. The incident photon to current efficiency (IPCE) curve is plotted as a function of wavelength, as shown in a photocurrent action spectrum of DCM-sensitized solar cell (Fig. 5(a)). In this spectrum, the dye was adsorbed at $60{ }^{\circ} \mathrm{C}$. The IPCE very closely corresponds to the absorption spectrum. The IPCE curve appears to cover the visible spectrum over a broad wavelength range, extending from 400 to $700 \mathrm{~nm}$ with a plateau region $(420-470 \mathrm{~nm})$, that is extremely low (4.7\%). Photovoltaic-photocurrent curves of $\mathrm{DCM}-\mathrm{TiO}_{2}$ electrodes prepared at 25 and $60{ }^{\circ} \mathrm{C}$ are compared in Figure 5(b). Therefore, it was found that the efficiency $(\eta)$ of the cell prepared at $60^{\circ} \mathrm{C}$ increased more than 10 times due to the effect of the amount of adsorbed dye on the 


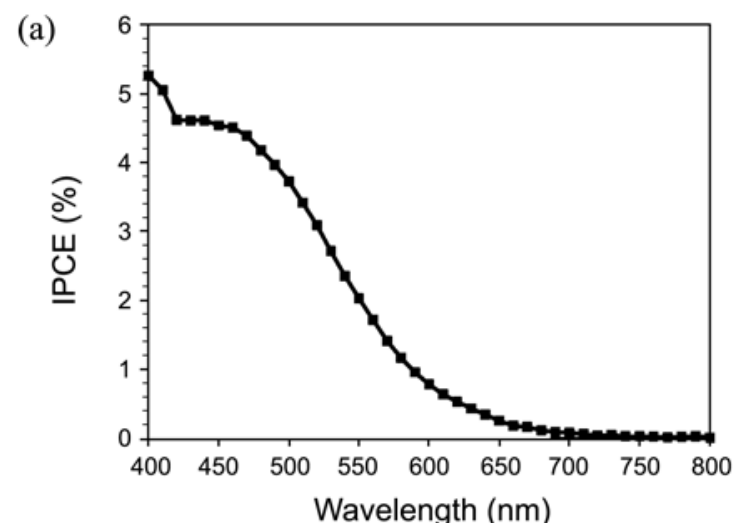

(b)

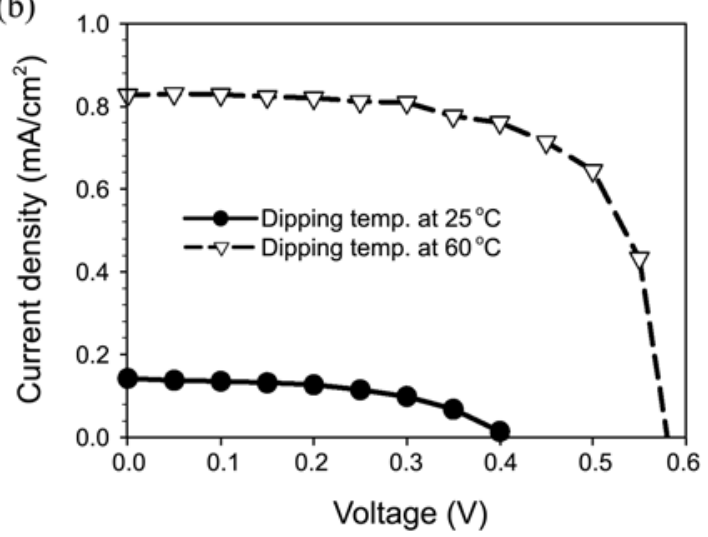

Figure 5. (a) IPCE curve of DCM-sensitized DSSC. (b) Photocurrent action spectra of DCM-sensitized solar cells using liquid iodide electrolytes.

Table 1. Detailed photovoltaic parameters of cells made with DCM at different dipping temperature

\begin{tabular}{ccccc}
\hline Cell & $J_{\text {sc }} / \mathrm{mA} \mathrm{cm}^{-2}$ & $V_{\text {oc }} / V$ & FF & $\eta / \%$ \\
\hline $\operatorname{DCM}\left(25^{\circ} \mathrm{C}\right)$ & 0.143 & 0.408 & 0.51 & 0.03 \\
$\operatorname{DCM}\left(60^{\circ} \mathrm{C}\right)$ & 0.862 & 0.581 & 0.68 & 0.34 \\
\hline
\end{tabular}

photovoltaic parameters. The open voltage $\left(V_{\mathrm{oc}}\right)$, shortcircuit photocurrent density $\left(J_{\mathrm{sc}}\right)$, fill factor $(\mathrm{FF})$ and $\eta$ were found to be $0.58 \mathrm{~V}, 0.86 \mathrm{~mA}, 0.68$, and $0.34 \%$, respectively. The photovoltaic parameters are also summarized in Table 1.

\section{Conclusion}

Sensitizers of DSSC are known to play key roles in the device efficiency. Thus, the development of new dye systems is inevitable to exceed the limit of DSSC efficiency, which has persisted over the last several years. As such, we assessed a nitrile dye DCM on DSSC for the first time. The DCM, when applied to DSSC, was showed to anchor strongly on $\mathrm{TiO}_{2}$ through the chelation, which was evidenced with the split vibrational stretching band of nitrile in FTIR as well as the broadened bands and strong red-shifted onset of the local bands in the absorption spectra of $\mathrm{DCM} / \mathrm{TiO}_{2}$.

DCM attracts significant attention due to the chelative formation from $\mathrm{TiO}_{2}$, and its dipolar nature, which is a critical condition of a DSSC sensitizer for the efficient electron injection from the $\mathrm{S} 1$ state to the conduction band. However, the photovoltaic parameters of DCM-sensitized DSSC are weak with low cell efficiency $(0.34 \%)$ and $J_{\text {sc }}(0.862 \mathrm{~mA}$ $\mathrm{cm}^{-2}$ ). The low efficiency is most probably due to the high back-electron-transfer rates from reduced $\mathrm{TiO}_{2}$ to the oxidized dye, which is a known problem of the Type-II dyes that chelates with $\mathrm{TiO}_{2}$, as catechol dyes. ${ }^{7,9,13}$ To clarify the cause of the low cell efficiency, the interfacial dynamics of the electron transfer between DCM and titania is on going using femto-second time resolved transient absorption spectroscopy.

\section{Experimental Section}

DCM was purchased from Aldrich and was used without further purification. Solvents for general purposes were commercial grade, and were redistilled prior to use. $\mathrm{TiO}_{2}$ paste (transparent) and $\mathrm{TiO}_{2}$ paste (light scattering) were obtained from Solaronix (Switzerland).

UV-vis spectra were recorded using a Perkin-Elmer Lambda 40 spectrophotometer. $\mathrm{TiO}_{2}$ films on $\mathrm{SnO}_{2}: \mathrm{F}$ (TEC$15,15 \Omega / \mathrm{sq}$ ) coated glass plates were prepared based on Grätzel's method: ${ }^{25}$ Adsorption of the dyes were carried out by placing the sintered, hot (about $80{ }^{\circ} \mathrm{C}$ ) $\mathrm{TiO}_{2}$ film into the dye solution $\left(10^{-4} \mathrm{M}\right)$ in acetonitrile at $60^{\circ} \mathrm{C}$ for $24 \mathrm{~h}$. After completion of the dye adsorption, the films were dried after rinsing in ethanol.

The photovoltaic measurements were performed immediately after the preparation of the dye-adsorbed films. Sandwich-type solar cells were assembled by clamping together the platinum coated $\mathrm{SnO}_{2}$ counter electrode ${ }^{14}$ and the dye adsorbed $\mathrm{TiO}_{2}$ working electrode with an active area of 0.2 $\mathrm{cm}^{2}$. A liquid electrolyte comprised 0.6 M BMII, $0.03 \mathrm{M} \mathrm{I}_{2}$, $0.1 \mathrm{M}$ guanidinium thiocyanate, and $0.5 \mathrm{M}$ 4-tertbutylpyridine in a mixture of acetonitrile and valeronitrile (volume ratio, 85:15) was introduced in between the two plates. Photocurrent voltage measurements were carried out using a Keithley model 2400 source measurement unit. A 300W Xe lamp was used as the light source, and the light intensity was adjusted using an NREL-calibrated silicon solar cell equipped with a KG-5 filter for one sun (AM 1.5). The IPCE spectrum was conducted as a function of wavelength from 400 to $900 \mathrm{~nm}$ using a specially designed IPCE system (PV Measurements, Inc.) for DSSCs.

Acknowledgments. The work was financed from University of Incheon (2009).

\section{References}

1. Grätzel, M. Nature 2001, 414, 338.

2. Tae, E. J.; Lee, S. H.; Lee, J. K.; Yoo, S. S.; Kang, E. J.; Yoon, K. B. J. Phys. Chem. B 2005, 109, 22513.

3. (a) O'Regan, B.; Grätzel, M. Nature 1991, 353, 737. (b) Hagfeldt, A.; Grätzel, M. Acc. Chem. Res. 2000, 33, 269.

4. (a) Wang, Z.-S.; Hara, K.; Dan-oh, Y.; Kasada, C.; Shinpo, A.; Suga, S.; Arakawa, H.; Sugihara, H. J. Phys. Chem. B 2005, 109, 3907. (b) Hara, K.; Dan-oh, Y.; Kasada, C.; Ohga, Y.; Shinpo, A.; 
Suga, S.; Sayama, K.; Arakawa, H. Langmuir 2004, 20, 4205. (c) Hara, K.; Sayama, K.; Ohga, Y.; Shinpo, A.; Suga, S.; Arakawa, H. Chem. Commun. 2001, 569. (d) Hara, K.; Sato, T.; Katoh, R.; Furube, A.; Ohga, Y.; Shinpo, A.; Suga, S.; Sayama, K.; Sugihara, H.; Arakawa, H. J. Phys. Chem. B 2003, 107, 597.

5. (a) Kay, A.; Grätzel, M. J. Phys. Chem. 1993, 97, 6272. (b) Campbell, W. M.; Burrell, A. K.; Officer, D. L.; Jolley, K. W. Coord. Chem. Rev. 2004, 248, 1363.

6. (a) Hara, K.; Kurashige, M.; Ito, S.; Shinpo, A.; Suga, S.; Sayama, K.; Arakawa, H. Chem. Commun. 2003, 252. (b) Hara, K.; Sato, T.; Katoh, R.; Furube, A.; Yoshihara, T.; Murai, M.; Kurashige, M.; Ito, S.; Shinpo, A.; Suga, S.; Arakawa, H. Adv. Funct. Mater. 2005, 15, 246.

7. Persson, P.; Bergstrom, R.; Lunell, S. J. Phys. Chem. B 2000, 104, 10348.

8. (a) Frei, H.; Fitzmaurice, D. J.; Grätzel, M. Langmuir 1990, 6, 198. (b) Moser, J.; Punchihewa, S.; Infelta, P. P.; Grätzel, M. Langmuir 1991, 7, 3012. (c) Tennakone, K.; Kumarasinghe, A. R.; Kumara, G. R. R. A.; Wijayantha, K. G. U.; Sirimanne, P. M. J. Photochem. Photobiol. A 1997, 108, 193. (d) Rajh, T.; Nedeljkovic, J. M.; Chen, L. X.; Poluektov, O.; Thurnauer, M. C. J. Phys. Chem. B 1999, 103, 3515. (e) Ramakrishna, G.; Ghosh, H. N.; Singh, A. K.; Palit, D. K.; Mittal, J. P. J. Phys. Chem. B 2001, 105, 12786. (f) Dimitrijevic, N. M.; Saponjic, Z. V.; Bartels, D. M.; Thurnauer, M. C.; Tiede, D. M.; Rajh, T. J. Phys. Chem. B 2003, 107,7368 .

9. (a) Wang, Y.; Hang, K.; Anderson, N. A.; Lian, T. J. Phys. Chem. $B$ 2003, 107, 9434. (b) Huber, R.; Spörlein, S.; Moser, J. E.; Grätzel, M.; Wachtveitl, J. J. Phys. Chem. B 2000, 104, 8995. (c) Ghosh, H. N.; Asbury, J. B.; Weng, Y.; Lian, T. J. Phys. Chem. B 1998, 102, 10208.

10. Cherepy, N. J.; Smestad, G. P.; Grätzel, M.; Zhang, J. Z. J. Phys. Chem. B 1997, 101, 9342.

11. Mulliken, R. S. J. Am. Chem. Soc. 1952, 74, 811.

12. Rice, C. R.; Ward, M. D.; Nazeeruddin, M. K.; Grätzel, M. New J. Chem. 2000, 24, 651 .

13. Ramakrishna, G.; Verma, S.; Jose, D. A.; Kumar, D. K.; Das, A.;
Palit, D. K.; Ghosh, H. N. J. Phys. Chem. B 2006, 110, 9012. Vrachnou, E.; Grätzel, M.; McEvoy, A. J. J. Electroanal. Chem. 1989, 258, 193.

14. Blackbourn, R. L.; Johnson, C. S.; Hupp, J. T. J. Am. Chem. Soc. 1991, 113, 1060 .

15. Yang, M.; Thompson, D. W.; Meyer, G. J. Inorg. Chem. 2002, 41, 1254.

16. Khoudiakov, M.; Parise, A. R.; Brunschwig, B. S. J. Am. Chem Soc. 2003, 125, 4637.

17. (a) Khoudiakov, M.; Parise, A. R.; Brunschwig, B. S. J. Am. Chem. Soc. 2003, 125, 4637. (b) Lu, H.; Prieskorn, J. N.; Hupp, J. T. J. Am. Chem. Soc. 1993, 115, 4927. (c) Weng, Y.-X.; Wang, Y.Q.; Asbury, J. B.; Ghosh, H. N.; Lian, T. J. Phys. Chem. B 2000, 104, 93. (d) Ramakrishna, G.; Ghosh, H. N. J. Phys. Chem. B 2001, 105, 7000. (e) Walters, K. A.; Gaal, D. A.; Hupp, J. T. J. Phys. Chem. B 2002, 106, 5139.

18. (a) Murata, T.; Saito, G. Chem. Lett. 2006, 35, 1342. (b) Murata, T.; Saito, G.; Nishimura, K.; Enomoto, Y.; Honda, G.; Shimizu, Y.; Matsui, S.; Sakata, M.; Drozdova, O. O.; Yakushi, K. Bull. Chem. Soc. Jpn. 2008, 81, 331.

19. Reddy, P. Y.; Giribabu, L.; Lyness, C.; Snaith, H. J.; Vijaykumar, C.; Chandrasekharam, M.; Lakshmikantam, M.; Yum, J.-H.; Kalyanasundaram, K.; Grätzel, M.; Nazeeruddin, M. K. Angew. Chem. Int. Ed. 2007, 46, 373.

20. Basham, J. I.; Mor, G. K.; Grimes, C. A. ACSNANO 2010, 4, 1253.

21. Mor, G. K.; Basham, J.; Paulose, M.; Kim, S.; Varghese, O. K.; Vaish, A.; Yoriya, S.; Grimes, C. A. Nano Lett. 2010, 10, 2387.

22. Hardin, B.; Yum, J.-H.; Hoke, E. T.; Jun, Y. C.; Péchy, P.; Torres, T.; Brongersma, M. L.; Nazeeruddin, M. K.; Grätzel, M.; McGehee, M. D. Nano Lett. 2010, 10, 3077.

23. Hardin, B. E.; Hoke, E. T.; Armstrong, P, B.; Yum, J.-H.; Comte, P.; Torres, T.; Fréchet, J. M. J.; Nazeeruddin, M. K.; Grätzel, M.; McGehee, M. D. Nature Photonics 2009, 3, 406.

24. Ito, S.; Murakami, T. N.; Comte, P.; Liska, P.; Grätzel, C.; Nazeeruddin, M. K.; Grätzel, M. Thin Solid Films 2008, 516, 4613 . 